\title{
Nonrandom X Chromosome Inactivation
}

National Cancer Institute

\section{Source}

National Cancer Institute. Nonrandom X Chromosome Inactivation. NCI Thesaurus.

Code C158134.

An indication that greater than $75 \%$ of cells in a sample demonstrate preferential inactivation of the same X chromosome. 